\title{
Florestan, o obscuro, e o liberalismo monárquico
}

CARLOS ÁGUEDO PAIVA

\author{
Somente o que é totalmente determinado é \\ também exotérico, é compreensível, capaz de ser \\ ensinado e de tornar-se propriedade de todos. \\ G.W.F. Hegel, A fenomenologia do espirito
}

S EM SOMBRa DE DÚvida, é mais fácil admirar do que entender Florestan Fernandes. Cioso de um rigor que leva até o hermetismo, Florestan é, simultaneamente, um autor heterodoxo e subversivo atropelando de forma recorrente e sistemática as fronteiras (pretensamente intransponíveis) que separam as distintas vertentes da sociologia científica e acadêmica.

Essa unidade contraditória entre rigor e (aparente) ecletismo não poderia deixar de se tornar um objeto privilegiado de reflexão de seus intérpretes e críticos. Em particular quando - com a publicação de A revolução burguesa no Brasil (a partir de agora, $R B B$ ) - fica evidente que, a despeito do caráter crescentemente radical de sua produção teórica, Florestan aposta no instrumental teórico da sociologia acadêmica para refletir sobre o desenvolvimento capitalista brasileiro. Tal opção analítica havia necessariamente de causar estranhamento e incompreensão nos meios de esquerda, gerando todo um debate em torno da qualidade (e da consistência) do marxismo de Florestan.

Não há como se pretender que este debate - cujos ecos se fazem sentir a cada momento em que a obra de Florestan é objeto de consideração de forma mais global (1) - seja falso e despropositado. Mas sua própria recorrência, nos mesmos velhos termos, revela o seu caráter truncado. Na verdade, diríamos ser este um debate que não diz tudo de si: propõe-se como uma avaliação (da ortodoxia, do academicismo, do marxismo) de Florestan. Do nosso ponto de vista, porém, sua base real é a percepção crítica (legítima, mas via de regra insegura e quase envergonhada) de que o hermético e sofisticado discurso florestanista em $R B B$ não fornece subsídios necessários e suficientes para o estabelecimento das conclusões ousadas e radicais da própria obra.

Para que se entenda tal ponto, é preciso primeiro reconhecer que a questão da tensão entre marxismo e ecletismo em Florestan só se impõe na medida que absolutamente não há como negar o caráter marxista do objeto deste autor em sua fase (por assim dizer) madura. E quando se fala aqui de objeto, fala-se também do objetivo: no Florestan de $R B B$, a reflexão teórica é militante e busca iluminar a ação política a partir de uma adequada caracterização dos determinantes estruturais das 
relações sociais de poder e conflito sob a ditadura. A radicalidade desse exercício teórico só pode ser avaliada se se levar em conta que ele projeta a necessidade de uma inflexão tática e estratégica da luta política dos trabalhadores em meados dos anos 70. Afinal, não poderia ser outro o resultado inferido de que (contra os teóricos do "capitalismo originário" brasileiro) a "revolução burguesa no Brasil" era um processo impositivo o qual, contudo (e ao contrário do que pretenderiam os teóricos da "hegemonia oligárquico-imperialista") já se rea-lizara sob a forma especificamente contra-revolucionária, sendo o "golpe de 64" sua conclusão necessária dentro do horizonte histórico de interesses burgueses (2).

Mas - e aqui o busílis da questão -, se o marxismo de Florestan se expõe de forma quase despudorada no seu objeto, parece se esvair no seu texto. Neste, nem as categorias analíticas, nem os fatores históricos tomados como referência da reflexão teórica parecem condizer com o padrão marxista de apreensão e exposição do objeto. Vale dizer: manifesta-se um gap entre o padrão analítico e o objeto/objetivo da própria análise. Um gap que se transmuta em pura tensão se se levar em consideração a radicalidade mesma das conclusões a que a análise sustenta e conduz. E é esta tensão que, do nosso ponto de vista, impõe uma discussão e dá consistência ao debate em torno da filiação teórico-metodológica de Florestan.

Só que, se se reconhecer a radicalidade do trabalho teórico de Florestan e sua refinada percepção das especificidades e contradições dos distintos paradigmas sociológicos, certas soluções fáceis para a tensão já expressa - do tipo "Florestan não era marxista em sua juventude e, quando assumiu esta perspectiva teórica, não conseguiu fazê-lo de forma radical" - não podem ser tomadas seriamente. $\mathrm{Na}$ direção oposta a tal tipo de solução, é preciso voltar ao texto de Florestan e buscar entender como o autor organizava (ou, pelo menos, pensava organizar) sua estrutura discursiva de forma a tornar sua apropriação de categorias e referências teóricas não-marxistas compatível com o objeto/objetivo da análise. É justamente nesse sentido que Gabriel Cohn situa a sua proposta de interpretação da $R B B$, em intervenção realizada no já referido Congresso de Marília. Nas palavras do autor: "Se acompanhássemos aqui os passos do texto que menciono sem demonstrar, veríamos que no que está explícito no texto, no que é facilmente reconstruível no texto do ponto de vista metodológico, aparecem constantemente formulações que são leitura direta de Weber e Durkheim. Eu afirmarei aqui dogmaticamente, sem demonstrar, que há passagens que são puro Weber e há passagens que são puro Durkheim nessa obra. E, se apanharmos essas passagens e as analisarmos, constataremos uma coisa desconcertante, a saber, que estas questões relativas à constituição de certos agentes sociais no contexto brasileiro, questões que são colocadas numa perspectiva que se apresenta no texto pelo menos à primeira vista como weberiana, são respondidas a partir de formulações referentes às condições estruturais em que esses agentes operam e essas segundas formulações são feitas no registro durkheimiano. Há então uma aparente discrepância: questões formuladas num registro teórico encontram respostas no outro registro. Como integrar isso? Eu me aventuraria a sugerir que seria um belo empreendimento de reconstrução metodológica e teórica se nós pudéssemos trazer à tona como, no final das contas, o jogo cruzado entre Weber e Durkheim, na análise que Florestan faz da 
revolução burguesa no Brasil, encontra a sua inteligibilidade numa outra corrente de pensamento, que permeia ambas e exatamente garante a sua inteligibilidade. Ela não está expressa, não está explícita, não é invocada de maneira explícita. ... Essa explicitação requer um trabalho de reconstrução para vir à tona.

A sugestão, aqui, é que essa outra concepção, essa coisa que trabalha o texto por dentro, é a visão marxista, é uma concepção materialista histórica, alimentada por Marx. Eu diria que não apenas por Marx, mas por Lenin, esse Lenin ao qual Florestan dedicou um texto que deve ser sério candidato a ser uma das melhores coisas que se tenha escrito como comentário a respeito: a introdução que Florestan fez ao volume sobre Lenin da coleção Grandes cientistas sociais" (3).

Há dois elementos centrais na interpretação feita por Cohn da tensão entre instrumental analítico e objeto na obra de Florestan. Em primeiro lugar, Cohn reconhece que esta tensão existe, de tal forma que a essência marxista do trabalho de Florestan "requer um trabalho de reconstrução [do texto] para vir a tona". Em segundo lugar (e por outro lado), Cohn nos diz que, se se reconstrói o texto de Florestan pelo pensamento, o que se vê é a tensão já referida ser antes formal do que real. E isto na medida que a apropriação do instrumental weberiano e durkheimiano por Florestan é feita de tal forma a forçar o diálogo das duas referências teóricas, desdobrando-as numa verdadeira dialética do sujeito e da estrutura e, como tal, num exercício de racionalização da (ou, antes, de desvendamento da racionalidade na) história (4).

A proposta interpretativa de Cohn é tão brilhante quanto esclarecedora (5), apesar de nos deixar uma questão por resolver: por que Florestan não estruturou este jogo dialético diretamente dentro do padrão expositivo marxista? Não encontramos em Cohn qualquer pista que nos ajude a solucionar tal problema. Mas em Florestan há algumas: a começar pelo subtítulo da obra que vimos tomando como referência: Ensaio de interpretação sociológica (6). Por que Florestan não subintitula seu trabalho maior de Ensaio de interpretação histórica? Simplesmente porque ele não é (em termos rigorosos) isso!... Na realidade, Florestan só pode dialetizar Weber e Durkheim (forçando-os a um diálogo por vezes incômodo) na medida que o escopo da análise a que se propõe em sua obra não é totalizante, mas especificamente sociológico. $\mathrm{Ou}$, como o próprio autor reconhece ao final do primeiro capítulo do RBB: "Na análise da emergência da 'Revolução Burguesa' no Brasil, vamos nos limitar, apenas, a um reduzido conjunto de fatores históricosociais que podem ser considerados ... como possuindo importância dinâmica tópica ... para os fins da investigação sociológica ... . Estes fatores podem ser identificados historicamente, através de um processo político (a Independência...); dois tipos humanos (o 'fazendeiro de café' e o 'imigrante'...); um processo econômico (mudança do padrão de relação dos capitais internacionais com a organização da economia interna); e um processo sócio-econômico (expansão e universalização da ordem social competitiva)" (7).

Mais, até, do que a referência explícita na sociologia acadêmica, é esta autocircunscrição teórico-objetal que vai aparecer aos leitores e intérpretes de Florestan como estando em contradição com o amplo e plurideterminado objeto de sua obra. E 
Florestan dá mostras de entender o verdadeiro sentido desta crítica, que normalmente se oculta atrás das acusações de hermetismo e ecletismo. Assim é que, no Prefácio à segunda edição da $R B B$, nos diz: “... há a questão da amplitude do capítulo 2. Na época em que o redigi, há dez anos atrás, parecia-me que a síntese feita, apesar de muito apertada, respondia a tudo que era essencial (especialmente tendo-se em vista que se trata de um capítulo 'de abertura', no qual são focalizados temas mais ou menos indiretos com referência aos pré-requisitos do desencadeamento da revolução burguesa). Tive de omitir-me, principalmente: 1) quanto ao passado colonial; 2) quanto aos momentos de conexão desse passado com a eclosão da fase de transição neocolonial. O que escrevi a respeito visava mais a uma autolocalização do autor do que a uma tentativa de explicação. Os 'problemas em suspenso' ficaram, assim, gravitando no próprio eixo teórico do fulcro de contenção histórica da descolonização. Para um sociólogo que se apega à sua condição socialista, isso não deixava de ser paradoxal. Os véus que nos prendem, ainda hoje, ao passado recente ficaram encobrindo a realidade, embora algo tenha sido definitivamente desmascarado. Logo que tive ocasião propícia, aproveitei-a para 'arredondar a conta'. Em um pequeno estudo, em vias de publicação, completei duas análises anteriores da sociedade escravista e fechei o círculo que ficava aberto na exposição contida neste livro. Nesse estudo, não só esclareço meu pensamento sobre a natureza, a estrutura e a evolução do modo de produção escravista, como completo a análise desenvolvida nesta obra sobre a maneira pela qual o modo de produção escravista funcionou como base material da ordem escravocrata e senhorial... Por conseguinte, não só os quadros da análise foram ampliados, mas também os seus focos teóricos (8).

A circunscrição da autocrítica acima aos limites do (particularmente complexo e mal entendido) segundo capítulo da $R B B$ deve ser bem interpretada. De fato, Florestan não pretende dizer aqui - nem poderia - que os demais capítulos da $R B B$ operam com quadros de análise e focos teóricos equivalentes aos de $A$ Sociedade Escravista no Brasil-SEB (9), um ensaio propriamente histórico, que opera em um campo rigorosamente materialista e totalizante. Se Florestan reflete apenas sobre os problemas de exposição e conteúdo do segundo capítulo é porque, neste, eles são levados ao seu máximo. Em primeiro lugar, porque não há qualquer consenso na literatura especializada sobre a lógica material de reprodução do "modo de produção escravista colonial" (10). Em segundo, porque a Independência não é apenas um movimento de transformação social de raízes primariamente políticas, mas um movimento que se realizará a partir da consolidação da ordem material escravista colonial; o que desde logo coloca a questão de se é possível caracterizar de materialista uma análise da Independência que a tome como processo revolucionário (11). E, em terceiro lugar (na ordem expositiva, mas não na de importância), porque, para Florestan, a adequada compreensão das peculiaridades do processo de constituição do Estado nacional a partir da Independência é condição para a compreensão do papel-chave dessa instituição no posterior desenvolvimento capitalista brasileiro (12).

Assim, é a complexidade e a importância do capítulo dois de $R B B$ que explicam a circunscrição da autocrítica de Florestan ao mesmo. Com a redação de $S E B$, 
nosso autor almeja colocá-lo em pé de igualdade com os demais, que já contariam com a sustentação de abundante e consolidada literatura materialista para o preenchimento dos elos históricos deixados em suspenso em sua obra maior.

O problema deste movimento de Florestan é que ele deriva, da disponibilidade de uma literatura voltada ao tratamento dos fundamentos materiais do processo de desenvolvimento capitalista brasileiro (em Caio Prado Jr., Celso Furtado, João Manuel Cardoso de Mello, entre outros), a conclusão de que tais fundamentos não precisam ser re-expostos em $R B B$. Dessa forma, nosso autor subestima a radicalidade das inovações analíticas presentes em sua obra. Uma radicalidade tal que leva qualquer leitor a se perguntar: o que sobra das (materia-listas ou não) análises anteriores? O que deve ser descartado e o que fica (ou pode ficar) em pé após esta revolução teórica? Não é fácil responder a tais perguntas, especialmente quando Florestan nos dá tão pouco apoio, e, via de regra, não apenas se exime de explicitar as fundações históricas de sua análise sociológica, como estrutura a mesma numa (tantas vezes obscura) dialetização dos dois paradigmas centrais da sociologia acadêmica.

$\mathrm{Na}$ verdade, o que se precisa é retomar a correta leitura/proposta de Cohn e reconhecer que "a explicitação [da essência materialista da obra de Florestan] requer um trabalho de reconstrução para vir à tona". De fato, tal trabalho mostrase necessário: não apenas para traduzir o diálogo Weber-Durkheim em termos marxistas; mas para pôr no interior dos argumentos de Florestan os elos históricomateriais que ele tão somente pressupõe.

Evidentemente, essa não é uma tarefa pequena, mas é tarefa que urge. Sob pena de algumas das maiores contribuições teóricas de Florestan perderem-se com o tempo por (contradição das contradições para um sociólogo!) não alcançarem uma socialização efetiva em função do esoterismo (essencialmente involuntário) do autor. E se é uma tarefa que urge, nada como a começar já. O que fica bem mais fácil se, seguindo a intuição e os passos do próprio Florestan, tomarmos um ponto polêmico do seu capítulo dois como matéria de (re)interpretação e (re)tradução. Afinal, o segundo capítulo é a legítima porta de entrada da RBB: é aqui que os leitores se abrem ou se fecham (por vezes, definitivamente) à compreensão desse trabalho maior; e é aqui que se encontra (e se esconde detrás de uma argumentação formalmente não-dialética e não-materialista) uma das mais complexas e sofisticadas contribuições teóricas de Florestan - o papel revolucionário do liberalismo na passagem da sociedade colonial para a sociedade nacional.

\section{Exercitando a exoterização do esotérico}

Sem jamais haver realizado uma verdadeira pesquisa sobre o tema, arriscarnos-íamos a dizer que o seu típico leitor é um estudioso de ciências sociais, buscando nesse trabalho uma reflexão crítica sobre o processo de desenvolvimento capitalista brasileiro, bem como sobre seu desdobramento na malfadada ditadura militar que se impõe a partir de 1964. Para este leitor - normalmente tão crítico de nossa perversa história social quanto avesso à historiografia tradicio-nal e à sociologia não-materialista - enfrentar a $R B B$ é tarefa extremamente árdua. Conhe- 
ci muitos que sobreviveram ao denso e metodológico primeiro capítulo, engoliram (com dificuldade, é evidente) a caracterização da Independência como "a primeira grande revolução social que se operou no Brasil" (13), mas definitivamente sucumbiram (enquanto leitores, bem entendido) à vigorosa caracterização da importância do liberalismo na Revolução da Independência que Florestan nos dá à página 38 de sua obra, onde se lê: “... o liberalismo foi a força cultural viva da revolução nacional brasileira. Guardando-se as proporções, a ele se pode aplicar, no acanhado cenário em que serviu de fermento para as mais variadas e contraditórias ousadias e esperanças, o que dele afirmou Laski como referência à Europa: 'O liberalismo aparece, pois, como uma nova ideologia para satisfazer as necessidades de um novo mundo"” (14).

Do nosso ponto de vista, a grande dificuldade em se aceitar tal interpretação do papel histórico do liberalismo diz respeito à (correta) sensação de inadequação do discurso e projeto liberal a uma sociedade que não apenas é, como se quer escravista e patrimonial. É isto que nos diz Roberto Schwarz em seu aplaudido As idéias fora de lugar: "É claro que a liberdade do trabalho, a igualdade perante a lei e, de modo geral, o universalismo eram ideologia na Europa também; mas lá correspondiam às aparências, encobrindo o essencial - a exploração do trabalho. Entre nós as mesmas idéias seriam falsas num sentido diverso, por assim dizer, original. A Declaração dos Direitos do Homem, por exemplo, transcrita em parte na Constituição Brasileira de 1824, não só não escondia nada, como tornava mais abjeto o instituto da escravidão. A mesma coisa para a professada universalidade dos princípios que transformava em escândalo a prática geral do favor" (15).

E, adiante: "Neste contexto, portanto, as ideologias não descrevem sequer falsamente a realidade, e não gravitam segundo uma lei que lhes seja própria - por isso as chamamos de segundo grau. (...) Deriva sossegadamente do óbvio, sabido de todos - da inevitável 'superioridade' da Europa - e liga-se ao momento expressivo, de auto-estima e fantasia, que existe no favor. Neste sentido dizíamos que o teste da realidade e da coerência não parecia, aqui, decisivo (...). Assim, com método, atribui-se independência à dependência, utilidade ao capricho, universalidade às exceções, mérito ao parentesco, igualdade ao privilégio etc. Combinando-se à prática de que, em princípio, seria a crítica, o Liberalismo fazia com que o pensamento perdesse o pé" (16).

Mas que não se entenda mal as passagens mencionadas. A caracterização de Schwarz do liberalismo como "idéia fora de lugar" não implica pretender que este discurso seja carente de função. A própria perda de pé do pensamento é funcional à dominação. Afinal, a contradição da realidade com as idéias liberais -"adotadas (...) com orgulho, de forma ornamental, como prova de modernidade e distinção" (17) - era tão flagrante, que alimentaria uma espécie de ceticismo crônico com relação às utopias progressistas e projetos políticos de transformação social.

Neste sentido, a crítica que cabe fazer a Schwarz a partir da perspectiva de Florestan não será a de incorreção, mas de insuficiência. E isto na medida que a funcionalidade do discurso liberal, para Schwarz, é eminentemente ideológica (no 
sentido negativo do termo); enquanto para nosso autor as idéias liberais no Brasil do século XIX não só comportam uma autêntica polarização utópica, como será esta a polarização mais expressiva e historicamente produtiva do nosso liberalismo. O que dificulta a visualização de tal dimensão é o fato mesmo de que, como nos alerta Florestan, “... as motivações ideológicas do liberalismo eram primariamente econômicas e apenas implicitamente políticas (...). As motivações utópicas do liberalismo, ao inverso, eram diretamente políticas e só secundariamente econômicas (o que está de acordo com a imagem que se fez e ainda se faz da influência do liberalismo; mas o que estava em jogo não era a ideologia liberal, como se pensava e ainda se pensa, mas a utopia liberal)" (18).

Cabe então perguntar por que usualmente se desvaloriza a dimensão especificamente política da Revolução da Independência. E a resposta a esta questão parece se encontrar menos na dificuldade dos distintos intérpretes do processo em reconhecer a importância da construção do Estado Nacional para a dinamização e transformação da vida econômica interna, do que na dificuldade em reconhecer os enormes obstáculos colocados para tanto. Subestima-se a complexidade da construção do Estado Nacional justamente porque se subestima a diversidade dos interesses e projetos sociais dos estratos dominantes, bem como a complexidade de construção da solidariedade em seu interior. O próprio Schwarz não deixa de pactuar dessa leitura ao dizer: "Esquematizando, pode-se dizer que a colonização produziu, com base no monopólio da terra, três classes de população: o latifundiário, o escravo e o 'homem livre', na verdade dependente. Entre os primeiros dois a relação é clara, é a multidão dos terceiros que nos interessa. Nem proprietários nem proletários, seu acesso à vida social e a seus bens depende materialmente do favor, indireto ou direto, de um grande. O agregado é a sua caricatura. O favor é, portanto, o mecanismo através do qual se reproduz uma das grandes classes da sociedade, envolvendo também outra, a dos que tem" (19).

Nada poderia ser mais avesso à leitura de Florestan. Boa parte de sua brilhante $S E B$ volta-se justamente para esclarecer a complexidade da estratificação social colonial. Para ele, sequer a relação entre escravos e senhores é clara ou simples. Afinal, a sustentação de um padrão de dominação escravista colonial - no qual parcela expressiva da repressão tem de ser internalizada ao domínio - impõe a diferenciação dos de baixo (20). E se a estratificação já se impõe no interior da casta subordinada, ela se aprofunda e se amplia no interior da casta dominante. Não há simplesmente senhores e agregados entre os homens livres. E não se impõe entre eles apenas relações de favor. Afinal, há diversos tipos de senhores, que estabelecem entre si os mais distintos padrões de relação - da mercancia à beligerância. Há o senhor de engenho, há o senhor sem engenho, e há até o senhor sem canavial. Este último - via de regra um terratenente da periferia do sistema pode ser um pecuarista, um muleiro, um preador de índios, um faiscador, um grileiro; pode estar mais ou menos integrado à economia mercantil, mais ou menos integrado à camada dominante, com sua situação de posse (e é sempre de posse que se trata (21), pois o estatuto da sesmaria reserva ao rei amplos direitos para retomar a terra cedida) mais ou menos regularizada. 
E não há só senhores - e seus agregados (22) - na vida colonial. Há os representantes da Coroa, o traficante de escravos, o financista, o comprador e exportador dos produtos coloniais, o atacadista e importador, o pequeno comerciante, o usurário, o artesão urbano, o contrabandista, entre outros. Com todos eles o senhoriato estabelece relação qualitativamente distinta da que mantém com o amplo (e diversificado) leque de dependentes aos quais se associa no interior do domínio. Tal relação pode ser mais ou menos tensa, mais ou menos solidária, mas sempre mediada socialmente, pois se estabelece para além do anômico espaço dominial. E, então, mesmo quando o privilégio (e o favor) se interpõe - o que é normal em uma sociedade de corte estamental -, é mediado (e, via de regra, subordinado) à conflituosa lógica mercantil-valorativa e/ou à complexa lógica política que equaciona a ação do Estado.

E nem poderia ser diferente. Afinal, o sistema colonial é um sistema que se gesta e se estrutura com vistas à acumulação de capital metropolitano. Seu eixo dinâmico é a produção para a exportação e sua reprodução depende da compra de insumos básicos - a começar pelo próprio escravo - fornecidos pelo mesmo capital mercantil que controla a conexão exportadora. $\mathrm{O}$ mero controle das condições de realização e reprodução material da célula escravista (base da exogeneização do excedente) já evidencia as contradições do senhoriato com um capital mercantil que - longe de se subordinar ao primeiro - controla, em última instância, a dinâmica da acumulação produtiva interna. Não será preciso dizer que tais contradições - ainda que transformadas - não se apagarão com a superação do estatuto colonial. Se o fim do exclusivo metropolitano é, por um lado, benéfico aos produtores internos, por outro, mina os elos não-especificamente-mercantis do capital comercial com o senhoriato. Para o moderno capital comercial inglês, o senhoriato brasileiro é um parceiro entre tantos outros, e, como tantos outros, descartável! Não é - como fora antes para o capital mercantil português - a boa e dócil teta da última vaca do decadente império lusitano. Da mesma forma, a mera nacionalização do tráfico não amenizará os conflitos e a dependência da lavoura para com os negreiros e para com os comissários que financiam a compra de peças. E se - pelo próprio caráter pré-capitalista do negócio - as relações de intercâmbio que se dão nesse âmbito não podem ser subsumidas à racionalidade fria da lógica mercantilburguesa; tampouco podem ser subsumidas à lógica do favor (23).

Mas se as relações do senhoriato com as distintas frações do capital mercantil já revelam a simplificação inerente à tentativa de subsumir a sociabilidade interna ao binômio dominação-favor; elas ainda não traduzem a sua complexidade. A adequada compreensão do problema exige ainda que se trate da complexa e nuançada relação intra-senhorial (vale dizer, do senhor com seus pares), bem como da relação (em grande parte reflexa da primeira) do senhoriato com o Estado metropolitano.

Para que se entenda a leitura de Florestan em torno das particularidades da relação intra-senhorial no mundo colonial, é preciso resgatar a discussão em torno das tendências autarquizantes do latifúndio escravista. Pelo menos desde Furtado, tornou-se um lugar comum reconhecer que a abundância de terras e a necessida- 
de de garantir a reprodução do patrimônio consubstanciado na escravaria coloca a autarquização como a alternativa econômica mais racional nos momentos de crise da lavoura exportadora. Porém - e ao mesmo tempo - é preciso entender que o padrão peculiar de controle da mão-de-obra associado ao escravismo impõe o relativo fechamento do domínio, mesmo nos períodos de auge da lavoura de exportação. E isso, à medida em que é preciso afastar o negro da mercancia, do contato com o mundo externo, do conhecimento de rotas e caminhos, do mundo do dinheiro e das trocas. Todo os negócios têm de estar centralizados na figura do senhor e de seus representantes imediatos. Em outras palavras, todos os negócios que não interessem ao senhor de forma direta e estrutural devem ser evitados, postos sob controle e, no limite, banidos do domínio. Objetivo que só se alcança com a sustentação permanente da dimensão autárquica do latifúndio (que, de quebra, garante a flexibilidade do sistema e sua rápida adequação às situações de crise da lavoura exportadora).

Mas se o sistema tende para a autarquização e busca preservá-la, o espaço para o desenvolvimento de relações mercantis-contratuais (a base histórica universal da articulação e tomada de consciência por parte dos estratos burgueses de seus interesses comuns) é estruturalmente limitado entre os senhores. Como o espaço de atuação e representação política na Colônia é acicatado ao máximo pelo poder metropolitano, e a vida urbana reflete as circunscrições impostas ao desenvolvimento de sua vida econômica e política, a perspectiva social do senhoriato se vêe impregnada pelos estreitos horizontes do "dominio", gerador de "uma autonomia e de um poder de mando que dividia e separava os iguais, tornando-os indiferentes ou beligerantes entre si" (24).

Evidentemente, com isso não se nega a consciência que os estratos dominantes tinham de seus privilégios comuns, nem o temor universal das fugas e rebeliões do inimigo interno. Só que a solidariedade baseada apenas no medo e na consciência do privilégio comum é estrutural e dinamicamente frágil; é capaz de alimentar ajustamentos conservadores, mas incapaz de articular uma resistência coletiva à espoliação metropolitana. É o que Florestan nos diz em um trecho de $S E B$ - no qual busca sintetizar a equação política colonial: "Trata-se de uma montagem política perfeita, que ainda hoje aparece como uma pequena obra-prima. Quisesse ou não, o senhor colonial era o 'parceiro válido' e, em última instância, o verdadeiro sustentáculo do Império no Brasil. Ao movimentar as contradições inerentes ao antigo sistema colonial 'dentro da ordem', ele favorecia inevitavelmente, e fortalecia a Coroa. Por sua vez, a própria estrutura e as contradições inerentes à ordem escravocrata e senhorial paralisavam o senhor colonial em tudo que dissesse respeito às contradições do mesmo sistema que só pudessem ser enfrentadas e resolvidas 'contra a ordem'. A massa dos escravos, de libertos e de mestiços pobres erguia o fantasma de uma rebelião geral, que poderia muito bem ter como estopim o 'inimigo doméstico' que era, ao mesmo tempo, o 'inimigo público'. Em si mesmo, para os estamentos senhoriais (ou para a chamada aristocracia colonial) esse risco era muito mais temível e indesejável que o pleno funcionamento do antigo sistema colonial" (25). 
Antes que se analise como será quebrado este círculo de ferro que aprisiona a ação política senhorial, é preciso resgatar a articulação teórica que subjaz à tese aqui exposta. Florestan engata a equação política colonial, o escravismo-mercantil e o horizonte cultural-político possível do senhoriato. O que o autor quer explicar, em última instância, é este horizonte cultural. Nesse sentido, o que faz é pura análise sociológica, mas articulada sobre sólidas (ainda que nem sempre explícitas) bases históricas e materialista. É dessas fundações que se extrairá a contradição dinâmica fundamental do sistema: a contradição que articula (e mina por dentro) a equação escravista-mercantil. Uma equação que tanto compromete o senhor com a lógica do lucro e da acumulação (e, portanto, com o desenvolvimento do mercado), quanto com a sustentação da ordem escravista, com seus desdobramentos na autarquização do latifúndio, no patriarcalismo e no caráter patrimonial do Estado (portanto, com a asfixia do mercado e da ordem social competitiva).

Nada poderia ser mais equivocado do que a subestimação dos reflexos dessa contradição na definição do jogo de alianças e do projeto político senhorial na nossa transição para a sociedade nacional, na medida que ela inviabiliza a caracterização simples e unívoca dos agentes mercantis - sejam eles velhos ou novos, nacionais ou estrangeiros, grandes ou pequenos - como aliados ou antagonistas. Eles são, todos, rigorosamente, radicalmente, "aliados" e "antagonistas" do negócio-dominio escravista-mercantil. Não no sentido simples em que, por exemplo, os distintos capitais são aliados (em nível da divisão intercapitalista do trabalho e do processo de reprodução do capital social global) e antagonistas (em nível da concorrência). Diferentemente da situação capitalista, no escravismo mercantil são o próprio projeto social e a dinâmica econômica mais geral dos distintos "aliados" que se contrapõem frontalmente a uma das faces - a "capitalista" ou a "dominial" - da grande lavoura escravista.

Tal síntese, abertamente contraditória de simbiose e antagonismo do senhoriato com seus parceiros econômicos e políticos válidos, vai se reproduzir em nível da relação do senhoriato com o Estado. Assim é que, em nível do domínio, a presença do Estado - enquanto representante dos múltiplos interesses articuladores da sociedade, de valores e regras que, em algum nível, se querem universais e alavancam a monopolização legal do uso da força física - é rechaçada, é inadmissível. Mas enquanto garantidor da dominação escravista, sustentáculo do tráfico, e calibrador das pressões anárquicas socialmente dissolventes e redistributivas da ordem mercantil em expansão, o Estado torna-se a condição por excelência da sustentação da contraditória ordem escravista-mercantil.

Não será preciso dizer que tal ambivalência do senhoriato com relação ao Estado articula no Brasil duas interpretações historiográficas clássicas e conflitantes. Autores que, atentos à dimensão dominial, perceberam corretamente a recusa à ingerência estatal sobre o latifúndio, traduziram essa percepção na tese de que a lógica de dominação senhorial era (proto, para ou quase) feudal. Por outro lado, aqueles que, atentos à dimensão mercantil (escravista) do latifúndio, perceberam (também corretamente) a importância do Estado como sustentáculo da reprodução (ampliada) das condições sociais de produção, se apressaram a identificar a 
dominação senhorial como dominação de classe, e o próprio senhor como a encarnação peculiar (até porque precoce) do burguês brasileiro. O problema é que a realidade - sempre, e teimosamente, tão complexa - se recusa a enquadramentos fáceis e solicita uma teorização que resgate a contradição pela raiz, reconhecendo que a lógica de dominação e reprodução do senhoriato escravista-mercantil tanto nega quanto exige o Estado, oposição que só se resolve num projeto de Estado muito peculiar, ao mesmo tempo "mínimo" e "máximo" .

Agora poderemos resgatar o fio da meada abandonado anteriormente e entender os limites do círculo de ferro que aprisionava o senhoriato ao Estado metropolitano e ao antigo sistema colonial na sua própria crise. Em função mesmo das determinações já referidas, não poderia partir do senhoriato um processo articulado e eficaz de resistência e oposição ao estatuto colonial e ao Estado português. Contudo, esse senhoriato tinha consciência de quão distante este Estado - que era mais presente no domínio do que seria desejável (26) e mais ausente de suas funções sociais de disciplinador da escravidão e do comércio do que deveria se encontrava de sua utopia de sociedade política. É essa consciência que vai ser o caldo de cultura de uma crescente oposição senhorial ao Antigo Regime, entendido como o conjunto do ordenamento político que faz do estatuto colonial uma peça (chave, mas não mais do que uma peça) do processo de contenção do poder econômico, político e social do senhor.

Pelas razões expostas, tal oposição será contida no momento da emergência da crise do antigo sistema colonial. Mas sua profundidade revelar-se-á a partir do momento em que o jogo das contradições entre os distintos parceiros/antagonistas do senhoriato colocar esse segmento social no centro da arena política. Em particular quando, com a transmigração da Corte - a tão expressiva resposta lusitana à crise do Antigo Regime aberta pela maturação da ordem econômica e social burguesa na Europa (27) - "O arcaico e rígido mercado colonial interno começa a esboroar-se, e em seu lugar começa a aparecer um mercado capitalista especificamente moderno" (28). Afinal, ao longo desse movimento, dois processos correlacionados ao fim do exclusivo metropolitano vão se desenvolver. Em primeiro lugar, a crescente conscientização senhorial de que a integração com o capital comercial inglês e o livre-cambismo não trazem apenas vantagens, mas também colocam problemas e incertezas que não podem ser adequadamente equacionados sem a colaboração do Estado. Uma consciência que brota justamente no momento em que o núcleo da sociedade política do império colonial português - em franca oposição à sua caracterização de Estado metropolitano instala-se na Colônia, objetivando-se na vida do colono como referência cultural e espaço de socialização. Neste processo, como diz Florestan, os “... estamentos senhoriais começam a ganhar existência própria, fora e acima do estreito palco fornecido pelo domínio patrimonialista e senhorial, do poder local e das pressões canalizadas institucionalmente de modo indireto sobre a Coroa. Eles não só começam a tomar consciência da comunidade de interesses econômicos, sociais e políticos numa linha integrativa estamental. Surgem as primeiras manifestações coletivas, embora regionais ou 'concentradas no tope', através dos figurões do Governo, de um 'querer coletivo' que iria articular-se de modo muito rápido” (29). 
Vale dizer, a precoce internalização do Estado servirá de instrumento para a articulação dos homens bons da antiga colônia, que rapidamente evoluirão de uma perspectiva política cujos horizontes eram dados pelo dominio para uma perspectiva especificamente estamental na qual "os privilégios sociais comuns [convertem-se] em fonte de solidariedade social e de associação política" (30). O que viabilizava essa transformação era o fato de que, no decurso do longo processo de autonomização "os estamentos senhoriais ... adquiriam meios para dar validade e eficácia à comunidade de interesses econômicos, sociais e políticos, isto é, para estender sua dominação do plano do domínio para o plano da coletividade (o que se operou gradualmente, mediante a absorção dos papéis administrativos, jurídicos e políticos configurados em torno da ordem legal emergente, ou seja, pela burocratização da dominação estamental)" (31).

Fossem menos profundas as contradições senhoriais com a própria ordem política que o Estado português transmigrado representava, ou fossem mais homogêneos e mais facilmente articuláveis os interesses deste estrato social e o duplo movimento de abertura comercial e incorporação de representantes do senhoriato à estrutura material-burocrática da sociedade política em reestruturação, teria sido suficiente para converter a surda oposição desenvolvida ao longo do período colonial em seu oposto. Contudo, não será esse o caso, como ficará bastante evidente apenas dois anos após a elevação do Brasil à condição de Reino-Unido, com a emergência da expressiva Revolução Pernambucana de 1817. Varnhagen - que deixa clara a sua antipatia pelo movimento - atribui a Antonio Carlos de Andrada à época ouvidor e corregedor de Olinda, que amargará quatro anos de prisão na Bahia em função de sua (discreta) participação no movimento - a melhor síntese dos reclamos dos sediciosos. Esse ilustre prócer da Independência nos diz: "Atualmente é esta capitania [de Pernambuco] uma das do Brasil mais comerciante e mais rendosa ao patrimônio régio, e cuido que a mais esquecida em providências favoráveis à sua prosperidade. Além do defeito natural de rios navegáveis e de estradas suficientes para suprir esta falta ... acrescem os defeitos morais de administração e governo. ... Murmura-se contra o modo parcial e fraudulento com que a Mesa de Inspeção nomeia os inspetores de algodão e açúcar, que hão de decidir com o seu voto da fortuna dos agricultores. Repete-se com clamor os prejuízos causados pela incapacidade das duas alfândegas. Faz-se o mesmo pela falta de socorros que tem a marinha mercante, em um porto aliás perigoso como este. Lastima-se finalmente a falta de polícia em geral ... [que nos obriga a elevar] preces ao altíssimo para nos escudar contra a falta de segurança pública" (32).

Em suma, reclama-se do fiscalismo estatal associado à centralização da arrecadação tributária, da incompetência dos administradores (reinóis) com referência aos reais interesses da região e da falta de segurança pública. O problema não é tanto que o Estado arrecade (ainda que o faça mal e demais), mas que ao invés de canalizar esta arrecadação para as regiões onde a mesma se dá, estimulando aí a lavoura, organizando (e disciplinando) o comércio e garantindo a ordem (escravista), o faça para sustentar (no Rio ou em Lisboa, pouco importa - uma corte improdutiva e fechada (para além das aparências) aos reais interesses da aristocracia da terra. No fundo, o que se exige é a descentralização e regionalização 
do poder. Demanda que, necessariamente levada ao limite no bojo dos movimentos sediciosos, se confundirá com o republicanismo e o federalismo extremado (quando não com o separatismo). Mas que não é, em si e por si, uma demanda republicana ou de secessão (como as tergiversações a esse respeito no movimento de 1817 , e nos demais que se erguerão com base nas mesmas bandeiras, o demonstram à exaustão). Enquanto tal, ela é uma demanda puramente "liberal" de abertura do Estado à participação livre e democrática do conjunto dos "cidadãos válidos" - vale dizer, do conjunto dos homens brancos e proprie-tários-da Nação em processo de construção.

Assim, do fracasso do movimento de 17 enquanto episódio particular, não se pode concluir qualquer inconsistência social de suas bandeiras. Até porque esse ano é apenas o primeiro momento de um amplo ciclo revolucionário (que apenas se esgotará na Praieira, em 1848). Um ciclo prenhe de momentos formal e objetivamente vitoriosos, como $1821,22,31$ e 34 (33). Por isto mesmo, a avaliação adequada do resultado de 1817 , assim como dos movimentos insurrecionais de base regional que lhe seguem, exige uma rotação de perspectiva. O que se tem de resgatar não é o seu resultado imediato, mas o jogo politico de negociações e as transformações que ocorrem a partir dos mesmos. Só quando adotamos tal perspectiva podemos compreender a revolução em curso, cuja vitória é ela mesma sustentada pela emergência e fracasso dos referidos movimentos. Na realidade - e é isto que se tem de entender -, os movimentos sedicio-sos não poderiam ser formalmente vitoriosos sem que a própria ordem social escravista - fundamento da unidade nacional (em construção) - fosse colocada em xeque. O que significa dizer que eles teriam de fracassar se os seus sustentadores em última instância almejassem vencer. Sua derrota formal é funcional à vitória real que se quer atingir! Afinal, seu significado para os segmentos proprietários das distintas regiões em processo de articulação (34) era afirmar, de forma clara e contundente, que os distintos interesses regionais (leia-se: os interesses dos distintos segmentos senhoriais, que equacionam de forma distinta sua esquizofrênica base dominial/mercantil) têm de ser levados em conta e incorporados, sistemática e institucionalmente, no interior da sociedade política nacional em gestação (35).

Evidentemente, o fato de ser essa a perspectiva que alimenta e orienta a radicalidade senhorial na transição da Independência não nos permite deduzir a sua vitória, como se estivesse de antemão estabelecida. Ainda mais quando se entende que tal vitória não seria possível sem a articulação de um projeto de Estado do qual a camada senhorial carece no emergir do movimento revolucionário pela sua própria inorganicidade política originária. Esta inorganicidade, contudo, vai ser enfrentada pelo seu chamamento à participação em movimentos políticos que não têm origem em sua intervenção. Os exemplos mais gritantes desse processo - mas, nem de longe, os únicos - são a Revolução do Porto e a convocação dos representantes brasileiros à Constituinte Portuguesa. Dessa experiência, da qual participarão alguns dos principais líderes do subseqüente processo de Independência, não restará apenas a consciência dos riscos associados à ambígua condição de Reino-Unido. Mais importante do que isso será a plena conscientização da plasticidade do projeto constitucional-liberal de organização politica, um ins- 
trumento ao mesmo tempo "rigido e maleável" de construção-consolidação do pacto social: rígido o suficiente para garantir a flexibilidade e a democratização do poder central; maleável o suficiente para incorporar em seu seio a defesa de uma estratificação social rígida e antidemocrática.

Mas se há um projeto (por assim dizer) disponípel, tem de haver agentes que com ele se identifiquem rigorosamente e que, assim, se mostrem aptos e dispostos a enfrentar a tarefa histórica de sua articulação objetiva. É aí que a análise de Florestan com relação a complexidade e pluralidade da ordem social colonial (em transição) se coloca no sentido de nos fazer ver que, na verdade, não apenas o segmento do tope da ordem mercantil-escravista não se reduz ao senhoriato (vide $R B B$, p. 28 e ss.), como, no interior do segmento senhorial, emerge uma fração cujo horizonte histórico é iluminado por sua inserção mercantil absolutamente peculiar. Pensamos aqui no segmento senhorial ligado à produção-comercialização de bens para o mercado interno.

A expressão política dessa fração do senhoriato na consolidação do projeto liberal na Revolução da Independência - objeto do tão brilhante quanto subvalorizado trabalho de mestrado de Alcir Lenharo (36) - não pode ser dissociada de seu perfil econômico e regional. Por sua natureza menos lucrativa, essa produção/comercialização articula-se numa extensa periferia do sistema que, avançando do RS ao centro-sul nordestino, tem como epicentro o velho oeste paulista e os entornos da decadente região aurífera de Minas Gerais (37). A importância desse perfil regional diz respeito, em primeiro lugar, à identidade do segmento senhorial vinculado aos negócios mercantis internos com os protestos (originados em outras camadas do senhoriato) contra a centralização do poder que caracteriza o Antigo Regime (português transmigrado). Por outro lado, e diferentemente das frações periféricas e decadentes do senhoriato ligado aos negócios de exportação, os horizontes econômicos do senhor-tropeiro (se nos é permitida uma caracterização quase bufa, mas expressiva) tornam-no um defensor intransigente da unidade nacional. Finalmente, sua menor capitalização (traduzida por menor intensidade da acumulação escravista, bem como maior abertura para formas alternativas de subordinação do trabalho) e o próprio caráter do negócio a que se associa, o tornam menos temeroso das conseqüências sociais potencialmente corrosivas (para o domínio) da internalização da ordem política liberal. Antes pelo contrário, tal ordem política - com a regulamentação das relações civis-contratuais que a acompanha - é a condição necessária para a superação dos riscos inerentes ao desenvolvimento de relações comerciais e financeiras no interior da sociedade estamental brasileira. Vale dizer: o Estado terá de garantir o cumprimento dos contratos e das relações de débito e crédito que se estabelecem (necessariamente, dado o perfil da estratificação social interna) entre senhores e senhores-comerciantes, colocando o direito de propriedade - e sua própria autoridade politica - acima da ordem estamental-dominial (38).

Nessa perspectiva, fica claro que os horizontes político-econômicos do senhor-tropeiro não apenas sintetizam e articulam os interesses mais gerais do senhoriato no que diz respeito à exigência (contraditória) de um Estado minimo- 
máximo, mas avançam com relação a eles, confundindo-se e amalgamando-se com os interesses gerais dos agentes comerciais internos e externos. Não se pode subestimar a importância dessa segunda articulação. Na realidade, ela completa a reflexão desenvolvida até aqui, reconduzindo-nos ao seu início. Afinal, se a própria emergência da resistência senhorial ao estatuto colonial e ao Antigo Regime (português) é indissociável de sua articulação com o novo capital comercial internacional que se gesta na esteira da Revolução Industrial, a conclusão desse processo não poderia deixar de se dar em consonância com os mesmos interesses. Só que - ao contrário do que já se pretendeu - admitir essa obviedade não resolve a questão. O que deve ser entendido (e que, na esteira de Florestan, vimos perseguindo até aqui) é a forma como tal conexão se dá dentro de um processo interno de gestação do Estado e da sociedade genuinamente nacionais. Nesse sentido, a dimensão realmente importante da conexão agora resgatada é que, se se tem em conta as perspectivas históricas da fração politicamente mais arrojada do senhoriato, fica claro sua permeabilidade ao projeto de ordenamento legal-institucional articulado pelo capital comercial forâneo não se assentar essencialmente na capitulação material e ideológica frente aos interesses externos. Por contraditório que seja, é preciso se reconhecer que o senhor-tropeiro tem interesses estratégicos que o comprometem (também) com a circunscrição do poder especificamente estamental do conjunto do senhoriato e do Estado escravista. A conquista dessa circunscrição passa por uma aliança estrutural com o forte capital comercial externo, bem como com a sua fração endogeneizada, identificada com a figura do imigrante (39).

Como já mencionado, com o resgate re-perspectivado da conexão senhorial com o capital comercial de origem externa, a cobra morde o rabo e fecha-se o circuito teórico. Ao fechá-lo, o que se obtém não é apenas a compreensão da funcionalidade do discurso/projeto liberal para cada um dos distintos segmentos sociais em disputa/articulação ao longo da Revolução da Independência, mas a particular operacionalidade desse projeto/discurso para a articulação de segmentos e interesses formal e objetivamente contraditórios. Assim, a defesa liberal da propriedade privada será, nos quadros históricos particulares da construção da nossa sociedade nacional, tanto a defesa do domínio e da autonomia senhorial no trato com os seus negros-capital, quanto a defesa e a garantia das relações contratuais mercantis que projetam a subordinação da ordem estamental à emergente ordem competitiva. Da mesma forma, a defesa do Estado constitucional e representativo é tanto a garantia da subordinação da sociedade política à sociedade civil e da abertura democrática da primeira ao conjunto (amplo e plural) dos cidadãos-válidos, quanto é a garantia de que o Estado será, acima de tudo, um Estado senhorial e escravista. Foi essa ambivalência de função do discurso/projeto liberal que ofuscou a tantos intérpretes e os levou a concluir pelo seu caráter eminentemente farsesco e demonstrativo. Na verdade, como já nos disse Florestan, "essa correlação entre o 'velho' e o 'novo' evidencia que o Estado preenchia funções sociais manifestas em dois níveis distintos. As elites dos estamentos senhoriais precisavam dele, quase na mesma proporção: 1) para manter as estruturas sociais que poderiam privilegiar seu prestígio social e, portanto, conduzi-las ao monopólio social do 
poder político; 2) para expandir ou fomentar o aparecimento de condições econômicas, sociais e culturais que deveriam formar o substrato de uma sociedade nacional. O que tem tornado precária e difícil a distinção é que o primeiro aspecto, por ser chocante na emergência de uma Nação do 'novo mundo', é mais visível que o segundo. Mas este não só existiu. Foi ele que tornou possível o êxito da Independência e a continuidade do Império, pois era dele que partiam as forças mais ou menos profundas de inovação e reconstrução" (40).

E, como Florestan também sabe, é a polarização utópica e modernizante dessa síntese contraditória entre velho e novo que está no sentido da história. É ela que, ao longo do processo, irá se tornar hegemônica, sinalizando e articulando os destinos da Nação, na medida que "as condições histórico-sociais imperantes favoreceram, singularmente, o rápido envolvimento [do conjunto dos] segmentos das elites senhoriais [com a ordem institucional requerida pela sociedade moderna] e, o que é mais importante, imprimiram à modernização amplitude, proporções e intensidade consideráveis para uma sociedade literalmente submersa no tradicionalismo. O setor que eventualmente poderia resistir às mudanças encontrava nelas um meio para conquistar autonomia real e para assumir o controle politico da Nação emergente. Doutro lado, como ele próprio regulava e conduzia, através de suas elites, as diferentes fases do processo, nada tinha a temer das inovações socioculturais e tudo tinha a ganhar do que elas representassem para a 'organização nacional' " (41).

Escusado dizer que o processo de modernização assim aberto prescindirá de qualquer ruptura formalmente revolucionária com a nova-velha ordem. $\mathrm{Na}$ verdade, o velho só terá de ser enfrentado à medida (sempre restrita) em que, de fato, antagoniza o moderno. Em outras palavras, a síntese dos dois sustentar-se-á a partir das características que os articula desde o início: o descompromisso com a democratização da ordem social e a conseqüente socialização dos benefícios da modernização. Descompromisso que não torna a modernização em curso, nem sua expressão ideológico-institucional, artificial ou farsesca. Torna-as apenas o que são: contraditórias, complexas e profundamente perversas.

\section{Conclusão}

A análise que Florestan faz do significado histórico do discurso/projeto liberal na emergência de nossa Revolução Burguesa fala tanto do Brasil quanto de certo projeto teórico (que é também político). Do Brasil, conta-nos o segredo da montagem original que viabilizará a transição burguesa como um processo formalmente contra-revolucionário e que se verá articulado a partir do interior do próprio Estado.

Só que, ao desvendar esse segredo, Florestan desnuda também as falsas soluções para o imbróglio, sejam elas a da aliança oligárquico-imperialista, a do capitalismo-escravista-colonial ou a do Estado demiurgo. E - interessante - não o faz para dizer que as três soluções são falsas (nem poderia). Ao contrário, Florestan afirma serem as três verdadeiras. Afinal, a realidade - sempre e insistentemente rica e contraditória - comporta todas ... e as determina. 
E aqui já se apresenta o projeto teórico de Florestan. Não que sua essência seja dada pelo exercício de síntese de leituras teóricas formalmente contraditórias (um exercício que, levado ao limite, apenas poderia sustentar um ecletismo sofisticado). O que realmente importa é que, por trás da síntese, há teoria. Uma teoria articulada sobre a convicção - aparentemente simples, mas plena de conseqüências de que, sendo (materialmente) determinado, o processo histórico é racional e teorizável.

É a força dessa convicção que sustenta e orienta o trabalho quase detetivesco de descobrir o lugar que a idéia liberal ocupa na organização da sociedade política nacional. Sem dúvida seria mais fácil caracterizá-la como uma idéia fora de lugar. Mas o peso da formação sociológica - em particular das influências de Durkheim, Weber e Marx - não o permite. Como poderia ser fora de lugar a idéia que articula uma resistência e define a forma material do Estado emergente? Evidentemente, tal idéia tem de ter uma função. E essa função não pode ser apenas de encobrimento, de deslocamento. Nem pode vigir de forma essencialmente inconsciente, uma vez que sustenta um projeto político de transformação que será levado à frente por agentes específicos em função de seus interesses e perspectivas históricas conscientes. Por outro lado, não há como (nem porque) negar o caráter ideológico do liberalismo, ou sua contradição com a base material escravista e o padrão patrimonialista de dominação social. Tais inferências nos levam a concluir que existe não uma única, mas múltiplas e concorrentes polarizações do liberalismo, cujo tensionamento interno acabará por definir a dinâmica e a projeção histórica desse projeto.

É bem verdade que a construção teórica de Florestan não é imune a críticas. No mundo da ciência, felizmente, nada o é. Mas não se pode negar o alcance e a produtividade dessa construção. Produtividade, aliás, rara nas ciências sociais, sempre em crise pela instabilidade das referências teórico-ideológicas dos pesquisadores e de seus objetos de pesquisa. Produtividade, portanto, que aguça a curiosidade e instiga a reflexão. Em particular numa época em que um novo liberalismo (o neo) polariza corações e mentes, atropelando sem qualquer respeito os prognósticos da economia e da ciência política críticas que apostavam na crise fatal de tal ideologia. Mais do que nunca, urge entender e responder a esse processo, o que só será possível se, seguindo Florestan, enfrentarmos as tentações da desqualificação (sempre mais fácil) ou do discurso abstratamente normativo, para nos dedicarmos à árdua tarefa de determinar o lugar efetivo dessas idéias

Notas

1 Veja-se, por exemplo, o conjunto de ensaios editados por Maria Ângela D'Incao a partir da I Jornada de Ciências Sociais de Marília (em D'Incao, M.A. O saber militante: ensaios sobre Florestan Fernandes. Rio de Janeiro, Paz e Terra, 1987). Como não poderia deixar de ser, a questão do ecletismo e do marxismo de Florestan perpassa (via de regra, sem que se ouse pretender resolver) a grande maioria dos trabalhos aí expostos. 
2 É evidente que, se a ditadura corresponde à consolidação do poder burguês no Brasil, a oposição a esta está além do horizonte dos setores hegemônicos e médios da burguesia (podendo corresponder apenas aos interesses circunstanciais daqueles setores perdedores na lógica competitiva e conjunturalmente marginalizados no interior da classe dominante). Ao mesmo tempo, se a forma autocrática é a forma necessária da consolidação do poder burguês, o reformismo radical de massas - traduzido em palavras de ordem que exijam a generalização dos direitos de cidadania - ganha foros de enfrentamento ao próprio padrão de dominação burguesa.

3 Cohn, Gabriel. O ecletismo bem temperado. In: D'Incao, Maria Angela (org.) op. cit., p. 51-52 (os grifos são meus). Diga-se de passagem, a referência de Cohn à influência de Lenin na leitura de Florestan é, do nosso ponto de vista, particularmente correta. Tal como procuramos demonstrar no terceiro capítulo de nosso trabalho de Mestrado, o conceito de revolução burguesa de Florestan só é perfeitamente compreensível se se retomar o Duas táticas da social-democracia na revolução democrática e as alternativas que Lenin vê para a conclusão da transição burguesa russa: ou a revolução se faz sob direção proletária - e vai além dos horizontes propriamente burgueses -, ou se realiza sob direção burguesa - e se realiza de forma contra-revolucionária e sem generalizar a ordem democrática. Não será preciso dizer que, para Florestan, a transição brasileira corresponde à forma perversa de transição anunciada por Lenin. Vide Paiva, C.A. Capitalismo dependente e (contra)revolução burguesa no Brasil: um estudo sobre a obra de Florestan Fernandes. Campinas, Unicamp, 1991 [mimeo].

4 Ao fazer dialogar as referências weberianas e durkheimianas, o que se obtém é a dinamização (e, no limite, historicização) de suas categorias de análise, no interior de um jogo de determinação/flexibilização das mesmas Em particular em $R B B$, é como se Florestan determinasse o sujeito social (tomado originalmente na referência weberiana) a partir da (re)referenciação de sua consciência possível à estrutura; e flexibilizasse a estrutura social (tomada originalmente na referência durkheimiana) a partir da (re)referenciação de sua forma (e de sua plasticidade) ao jogo de interesses e percepções conscientes dos agentes sociais válidos.

5 Interpretação, aliás, que, como o demonstrou Ianni em recente homenagem a Florestan (Ianni, O. A sociologia de Florestan Fernandes. In: Estudos Avançados, v. 10, n. 26, jan./abr. 1996), brota naturalmente de uma leitura atenta dos textos metodológicos desse autor. Um bom exemplo disto é Fernandes, F. Elementos de sociologia teórica. São Paulo, Nacional, 1974; em particular o seu capítulo quarto - A interação social -, no qual faz crítica à contraposição absoluta dos projetos de fundar a sociologia, seja diretamente na sociedade, seja nos indivídnos, a partir do reconhecimento de que a "interação social é, essencialmente, uma realidade dinâmica" (p. 75 ), o que não nos permite tomar nem a sua dimensão coletiva, nem a sua dimensão particular, estaticamente, como dados que existissem fora do tempo e da história.

6 Aliás, o contraste entre o título - mais do que provocativo - e o subtítulo - que não poderia ser mais acadêmico - é uma das expressões mais claras da tensão interna na obra de Florestan a que já nos referimos.

7 Fernandes, F. RBB. p 29-30.

8 Id., p. 6-7 (os grifos são meus).

9 Este é o "pequeno estudo, em vias de publicação" a que Florestan se refere, na verdade uma das mais belas peças literárias do autor, encontra-se em Fernandes, F. $O$ circuito fechado. São Paulo, Hucitec, 1976, p. 11 e ss. 
10 Sequer há consenso sobre a possibilidade de se caracterizar a sociedade escravista colonial como um modo de produção. O próprio Florestan aceita a caracterização cum grano salis. A esse respeito, ver a primeira seção do capítulo terceiro de Paiva, C.A.N., Op. cit.

$11 \mathrm{Ou}$, dito de outro modo: é compreensível (ainda que não seja defensável) que leitores menos acostumados à lógica da contradição tenham dificuldades em acompanhar Florestan na tese de que "a preservação de velhas estruturas e o privilegiamento dos estamentos senhoriais possuíam, na sociedade brasileira da época, um sentido revolucionário." Fernandes, F., RBB, p. 55.

12 Em particular, sem que se entenda este processo, não se alcança entender como o Estado brasileiro se tornou o locus privilegiado no qual a burguesia (tal como os estamentos hegemônicos antes dela) se organiza, toma consciência de sua diversidade e de seus interesses estratégicos, e articula o seu projeto global de dominação.

13 Cf. Fernandes, Florestan, RBB, $3^{\text {a }}$ ed. Rio de Janeiro, Zahar, 1981, p. 31.

14 Id., p. 38.

15 Schwarz, Roberto. As idéias fora do lugar. In: Ao vencedor, as batatas. São Paulo, Duas Cidades, 1977, p. 16.

16 Id., p. 17-18.

17 Id., p. 22.

18 Florestan, F., RBB, p. 50.

19 Schwarz. R., Op. cit., p. 16.

20 Assim é que, para Florestan, será grande a diferença de direitos e deveres dos escravos de lavoura e dos escravos da casa, dos escravos boçais e dos aculturados, que dominam um ofício, dos escravos próprios e dos de aluguel, dos escravos pagãos e dos cristianizados, dos escravos negros, dos índos, dos mestiços, dos bastardos, dos alforriados (sempre e necessariamente ex-escravos) etc. A esse respeito, ver Fernandes, F., SEB, p. 32 e ss.

21 Ver, a esse respeito, Porto, C. Estudo sobre o sistema sesmarial. Recife, Imprensa Universitária, 1965, em particular p. 116 e ss.

22 Cuja diversidade tampouco se pode subestimar: da parentela aos jagunços - passando, nos grandes domínios, pelo mestre-engenheiro, pelo padre, pelos posseiros habilmente (e, por vezes, temerosamente) tolerados - há os mais diversos tipos de dependentes. Só mesmo como caricatura poder-se-ia pretender subsumir o conjunto dessas relações à figura do agregado ou à caracterização genérica e indeterminada do favor.

23 Na realidade, as relações de intercâmbio entre os agentes urbanos responsáveis pela reprodução das condições de produção da lavoura tendem, de forma contraditória (pois essa tendência está associada à própria crise do tráfico e do escravismo), à racionalização mercantil-burguesa. $\mathrm{O}$ que significa dizer que ele tende à superação do asfixiante padrão simbiótico entre comissário e senhor (que, para além das aparências, nada tem a ver com o favor), no qual a alavancagem da acumulação urbana passava pela preservação do caráter dominial e pré-capitalista de administração da fazenda. 
24 Fernandes, F., RBв, p. 57.

$25 I d .$, sEB, p. 45-46.

26 Sobre a questão da presença do Estado no domínio ao longo da era colonial, é importante que se leia, além de $S E B$ de Florestan Fernandes, os capítulos quarto e quinto de Faoro, R. Os donos do poder. Porto Alegre/São Paulo, Globo/Edusp, 1975. Vale a pena observar que este último trabalho divide com $R B B$ de Florestan os méritos de reconhecer e determinar teoricamente a importância do liberalismo enquanto referência utópico-ideológica do projeto de construção do Estado nacional ao longo do processo de Independência. Nesta questão, aliás, os méritos de Faoro são particularmente notáveis. Afinal a leitura não se adequa perfeitamente à sua tese de continuidade essencial na forma política de dominação ao longo da história luso-brasileira, tal como Florestan; Faoro, porém, é tolerante com a contradição e recusa-se a esmagar a riqueza da história com argumentos (apenas aparentemente) lógicos.

27 Diga-se de passagem, não será preciso aceitar na íntegra a tese de Faoro que nega caráter feudal ao patrimonialismo português para reconhecer o caráter sui generis de uma sociedade na qual o Estado (e não apenas o rei ou a família real) abandona a Nação para se preservar íntegro.

28 Cf. Fernandes, Florestan, SEB, p. 48.

29 Id., ibid.

$30 I d ., R B B$, p. 41.

31 Id., ibid., p. 58

32 Apud Varnhagen, F.A. História Geral do Brasil. (t. V, v. III). São Paulo, Melhoramentos, 1978, p. 152-153.

33 1931-1934 perfaz, por assim dizer, um ciclo dentro do ciclo, que se inicia em 7 de abril e se encerra com o Ato Adicional de 12 de agosto de 1834. É bem verdade que este último, de tendências fortemente descentralizadoras, sofrerá restrições com a Lei Interpretativa de 1840. Só que esta reação centralizadora do Segundo Império (ao contrário do que pretenderia Faoro, R., Op. cit. p. 315 e ss.) não pode ser tomada como puro retrocesso. Na verdade ela mesma já é tributária da domesticação da Coroa e da consolidação de (sutis) mecanismos sociais de controle do exercício do Poder Moderador pelo Imperador (ver a esse respeito Fernandes, F., RBB, p. $44 \mathrm{e}$ ss.). Tal percepção, aliás, já se encontra em Joaquim Nabuco e está no centro de seu reconhecimento (a nosso ver correto) da autenticidade liberal da conversão conservadora de Bernardo Vasconcelos e Nabuco de Araujo (Nabuco, J. Um estadista do Império. São Paulo, Instituto Progresso Editorial, 1949; em particular p. 19 e ss., e p. 42 e ss.). Vai no mesmo sentido a análise de Uricochea do papel da Guarda Nacional enquanto instrumento de articulação estamental do senhoriato com vistas ao controle do Estado. A instituição, originária da Regência, consolidar-se-á e atingirá sua máxima eficácia como instrumento de articulação senhorial após a Maioridade (Urocochea, Fernando. O minotauro imperial: a burocratização do Estado patrimonial brasileiro no século XIX. Rio de Janeiro/São Paulo, Difel, 1978).

34 Sem que se desconsidere a importância no seu interior de outros agentes sociais, portadores de perspectivas utópicas e ideológicas mais radicais e - em parte por isso mesmo - historicamente derrotados.

35 A este respeito ver Fernandes, F., RBB, p. 68. 
36 Ver Lenharo, A. As tropas da moderação: o abastecimento da Corte na formação política do Brasil - 1808-1842. São Paulo, Símbolo, 1979.

37 Ver a este respeito, Fernandes, F., SEB, p. 24-25. É de se notar a passagem na qual Florestan vincula o desenvolvimento do café em São Paulo ao processo de capitalização deste agente mercantil interno ao longo da primeira metade do século XIX. Essa vinculação é tão mais expressiva na medida que o fazendeiro de café - em particular em seu segmento paulista - representará em $R B B$ (ao lado do imigrante) o papel de agente histórico representativo do processo de desenvolvimento da ordem social competitiva e de emergência da consciência propriamente burguesa em nível interno.

38 É importante observar que a reivindicação do senhor-tropeiro está longe de implicar um movimento simples de fortalecimento do Estado e enfraquecimento do domínio. No momento em que o Estado é alçado ao papel de garantidor das relações contratuais de débito e crédito e da propriedade privada, ele também passa a ser responsabilizado política e juridicamente por suas próprias dívidas, administração da receita orçamentária e da moeda, tendo de prestar contas das mesmas à sociedade civil senhorial-escravista, representada e articulada no Parlamento, nos partidos, na imprensa, e no próprio Judiciário. Além disso - e este é ponto de suma importância a plena consolidação da propriedade privada envolve o fim do regime sesmarial, que, com toda a sua ampla e barroca legislação, se tornou ao longo do período colonial um dos mais perversos e eficazes instrumentos de controle do senhoriato pelo Estado patrimonial português. Sobre tais pontos, ver o importante trabalho de Bosi, A, A escravidão entre dois liberalismos. In: Estudos Avançados, v. 2, n. 3, set./dez. 1988.

39 Visto de outra perspectiva, o reconhecimento dessa unidade de interesses nos ajuda a entender o esgotamento do ciclo revolucionário da Independência com a Praieira. Como já observou Joaquim Nabuco, a despeito da inegável expressão popular do movimento, ele contará (em franco contraste com os movimentos pernambucanos de 1817 e 1824) com pouco ou nenhum apoio do senhoriato. Tal fato - ainda segundo o autor - traduziria o caráter limitado (e, no limite, antimodernizante) da principal palavra de ordem do mesmo, a nacionalização do comércio, reivindicação inconsistente com os interesses daquele estrato social. De outro lado, vale a pena observar que a unidade observada entre o senhor-tropeiro e o imigrante-comerciante já anuncia a unidade posterior (à qual Florestan dará tanta importância) entre o fazendeiro do café e o imigrante-comerciante-industrial.

40 Fernandes, F., RBB, p. 47.

41 Id., ibid., p. 65.

RESUMO - Neste trabalho procuramos discutir e determinar a polêmica tese de Florestan da centralidade do liberalismo na Revolução da Independência no Brasil. Para tanto, começamos por criticar o padrão expositivo adotado por Florestan em $A$ revolução burguesa no Brasil, que prejudica a adequada apreensão dos fundamentos histórico-materiais da polarização utópica e revolucionária do liberalismo na primeira metade do século XIX. Dessa crítica, extraímos uma proposta de retradução da leitura de Florestan com vistas a tornar explícitos os referidos fundamentos; movimento que procuramos efetivar na segunda parte do trabalho. 
ABSTRACT - The aim of this paper is to discuss and to determine Florestan's polemical thesis about the role of liberalism along the Independence Revolution in Brazil. We begin our discussion of this thesis criticizing the pattern of exposition adopted by Florestan in A revolução burguesa no Brasil. This pattern of exposition makes it difficult to learn the material and historical fundamentals of liberalism utopic polarization during the first half of the nineteenth century. From this criticism we extract a proposal of translating Florestan's work, as a way of clarifying it and making the material fundamentals that structure it explicit. Developing and presenting a particular proposal of translation is our goal in the second part of this paper.

Carlos Águedo Paiva é professor assistente do Departamento de Economia da Universidade Federal de Uberlândia (UFU) e doutorando do Instituto de Economia da Unicamp. 